\title{
Review
}

\section{Flap Thickness as a Predictor of Root Coverage: A Systematic Review}

\author{
Debby Hwang* and Hom-Lay Wang*
}

Background: Thick gingival tissue eases manipulation, maintains vascularity, and promotes wound healing during and after surgery. A few recent case reports correlate greater flap thickness to mean and complete root coverage after mucogingival therapy for recession defects. The aim of this systematic review is to appraise the current literature on this subject and to combine existing data to verify the presence of any association between gingival thickness and root coverage outcomes.

Methods: Human studies that reported the number and class of recessions, measured flap thickness at a well-defined location, described the method of root coverage used, followed results for at least 3 months, and detailed mean root coverage underwent review and statistical analysis. Investigations were scored from 1 to 5 based on methodological quality. Weighted gingival thickness and weighted mean root coverage was calculated based on standard error. Statistical analysis used the Mann-Whitney test, analysis of variance (ANOVA), and linear regression to determine any correlation between a number of factors (i.e., thickness, treatment type, and follow-up time) and mean and complete root coverage. A significant $P$ value was set at $<0.05$.

Results: Fifteen investigations met the inclusion criteria. All of these reported at least $0.7 \mathrm{~mm}$ of flap thickness, although measurement locations varied. Treatment modalities included coronally advanced flap, connective tissue graft, and guided tissue regeneration with and without adjuncts. A significant moderate correlation occurred between weighted flap thickness and weighted mean root coverage and weighted complete root coverage ( $r=0.646$ and 0.454 , respectively). According to Mann-Whitney analysis, a critical threshold thickness $>1.1 \mathrm{~mm}$ existed for weighted mean and complete root coverage $(P<0.02)$. The type of treatment rendered also influenced root coverage. Further simple linear regression revealed a high correlation between weighted thickness and weighted mean root coverage in connective tissue grafting and guided tissue regeneration $(r=0.909$ and 0.714 , respectively) but not coronally advanced flap therapy. Study score and follow-up time did not affect the percentage of root coverage.

Conclusion: Within the limits of this review, a positive association exists between weighted flap thickness and mean and complete root coverage. J Periodontol 2006;77:1625-1634.

\section{KEY WORDS}

Connective tissue; gingiva; guided tissue regeneration, periodontal; surgical flaps.
A n oft-cited prerequisite for surgical success, gingival thickness has not garnered formal scientific evaluation until recently. Nonetheless, abundant empirical evidence suggests that thick tissue, subjectively determined, resists trauma and subsequent recession, enables tissue manipulation, promotes creeping attachment, improves implant esthetics, exhibits less clinical inflammation, and renders predictable surgical procedures. ${ }^{1-11}$ A dense gingival biotype may reflect underlying osseous morphology; that is, the thicker the gingiva, the greater its bony support. ${ }^{3}$ However, this is not always the case. By itself, thick soft tissue has two factors that encourage its survival. The first, a high volume of extracellular matrix and collagen, allows it to withstand collapse and contraction. Likewise, more layers of epithelial keratinization deflect physical damage and microbial ingress. The second and arguably more essential factor is its increased vascularity. Greater perfusion enhances oxygenation, clearance of toxic products, immune response, and growth-factor migration. In short, it boosts wound healing. Supraperiosteal vessels, for the most part, feed the free and attached gingiva in a caudocranial direction (vestibule to gingival margin [GM]). ${ }^{12-14}$ Anastamoses

doi: $10.1902 /$ jop.2006.060107 
of these structures and vessels from the bone and periodontal ligament (PDL), whose major sources are the superior and inferior alveolar arteries, exist such that some collateral circulation occurs upon surgical trauma. Flap survival depends on the degree of primary and collateral blood supply. ${ }^{15-22}$ Ischemia results from a lack of either. Full-thickness flaps preserve gingival vascular patency and display dilation of the supraperiosteal vessels; if there is proper tissue adaptation, revascularization between flap and underlying bone establishes within days. ${ }^{23,24} \mathrm{Be}-$ cause flap vasculature is left intact, the wound usually heals, individual anatomical variations in the level of collateral blood supply notwithstanding.

Conversely, split-thickness flaps leave fewer gingival capillaries intact, and subsequently, rely heavily on the compensatory blood flow from bone and PDL. If few vessels exist (i.e., thin bone and unusually sparse vasculature) or if the flap itself has too few patent arterioles, necrosis results. ${ }^{14,25-30}$ Indeed, Wood et al., ${ }^{31}$ and others, ${ }^{32,33}$ observed that partial thickness flaps lost more radicular bone than their mucoperiosteal counterparts $(0.98 \mathrm{~mm}$ versus $0.62 \mathrm{~mm}$, respectively), contrary to previous reports. Wood et al. ${ }^{31}$ attributed this amplified loss to thin connective tissue (CT); partial dissection of this biotype led to severing of the few vessels present and eventual flap death. ${ }^{31}$ Therefore, hypothetically, a thin full-thickness flap may react similarly to a split-thickness flap over an avascular area. Separated from its underlying collateral source, a thin full-thickness flap may not have sufficient blood supply to support itself, let alone a graft or other material inserted below it. Thus, the thicker the gingiva, the better the blood supply.

It is intuitive that copious tissue facilitates periodontal stability, especially after treatment. But how much tissue does one require? What dimension defines thick gingiva? Where should it be measured? How should it be measured? Where should it be thickest (e.g., base, radicular area, margin, or papilla)? With respect to these issues, the literature is somewhat inconsistent. Claffey and Shanley ${ }^{34}$ reported that subjects with gingiva $\leq 1.5 \mathrm{~mm}$ thick at a midbuccal location lost attachment after supra- and subgingival debridement. No sites with mucosa $\geq 2 \mathrm{~mm}$ receded. On the other hand, Anderegg et al. ${ }^{35}$ described less mean recession in molar teeth covered by flap tissue $>1 \mathrm{~mm}$ than those covered by tissue $\leq 1 \mathrm{~mm}$ after guided tissue regeneration (GTR) treatment for buccal furcations. They measured thickness at a mid-buccal location $5 \mathrm{~mm}$ apical from the GM.

Perhaps the therapy most influenced by gingival thickness is plastic surgery; at least the vast majority of publications on this subject involve root coverage procedures. Tissue type is essential for grafting, whether it entails pedicle-based therapies (i.e., rota- tional or coronal advancement flaps) or grafts acquired from a separate donor site (i.e., CT), as it reflects vascularization. McFall ${ }^{36}$ listed the thickness of tissue in the receded area and in the donor site as key factors in the treatment selection of mucogingival defects. A thicker recipient site should promote root coverage and resist further recession. An early study on pedicle flaps in pigs demonstrated that subjectively thick flaps survived twice as often as thin flaps (55.7\% versus $26.5 \%$, respectively) and that thin flaps relied mostly on collateral circulation from the recipient bed for oxygen and nutrients. ${ }^{37}$ In an influential exploration, Allen and Miller ${ }^{38}$ treated 37 shallow Class I recessions $(<4 \mathrm{~mm}$ deep) with coronally advanced flaps (CAFs) in gingival biotypes exhibiting $\geq 1 \mathrm{~mm}$ thickness, again determined subjectively and at an undisclosed location. They achieved complete root coverage in $84 \%$ of sites at 6 months. Five out of six sites with incomplete coverage displayed only $\leq 0.5 \mathrm{~mm}$ of root exposure, a clinically insignificant amount. Although the investigation suffered from a lack of comparison with thinner tissue and deficient measurement methodology, it spurred later investigators to evaluate more rigorously the effect of gingival thickness on recession treatment. Harris addressed this issue in a root-coverage trial comparing the CT-double papilla graft and GTR with a bioabsorbable membrane. ${ }^{39}$ Harris considered recipient gingiva thin, and presumably $<0.5 \mathrm{~mm}$, if a periodontal probe could be read through it; in contrast, thick gingiva did not allow for probe visualization. Despite this arbitrary categorization, mean root coverage exceeded 95\% for all combinations of tissue type and treatment modality except GTR performed in areas of thin tissue, which garnered only $27 \%$ of mean coverage. Perhaps the membrane, placed between the full-thickness flap and the bone, obstructed the collateral circulation essential for a thin flap to revascularize and heal.

At present, the literature regarding tissue thickness and root coverage is still in a nascent stage. Papers vary greatly with respect to the therapy used, measurement technique, randomization, follow-up time, and types of defects treated. Therefore, the aim of this study was threefold: 1) to collect and summarize clinical data from root coverage studies analyzing gingival flap thickness in a systematic fashion; 2) to encourage study standardization to make possible future comparison reviews and meta-analyses; and 3) to detect any emerging trends from the existing literature.

\section{MATERIALS AND METHODS}

\section{Search Protocol}

An online search for human clinical studies in the English language was performed using MEDLINE, PreMEDLINE, and the Cochrane Oral Health Group trials register. Publications from January 1960 to January 
2006 were selected based on the following search terms: "recession," "gingival thickness," "tissue thickness," "flap thickness," and "root coverage." All of the search terms were combined with "periodontal." A hand search of International Journal of Periodontics and Restorative Dentistry, Journal of Clinical Periodontology, Journal of Dental Research, Journal of Periodontal Research, and Journal of Periodontology was also executed. Abstracts culled from these searches were screened. Relevant papers were chosen according to fixed inclusion and exclusion criteria. Out of 57 references published between 1979 and 2006 generated by the search protocol above, 15 papers, all published between 1999 and 2006, met the criteria established for this review.

\section{Inclusion Criteria}

Screening occurred for randomized controlled clinical trials (RCTs), cohort studies, case-control studies, and case reports. All chosen studies detailed the following: 1) number and class of treated recessions; 2) measurement of flap thickness at a well-defined location at baseline; 3 ) description of the root coverage procedure performed; 4 ) at least 3 months of follow-up post-surgery; 5) report of mean root coverage; 6 ) sufficient number of patients to render statistical analysis possible; and 7) detailed statistical methodology.

Any of the following treatment interventions were integrated into our analysis: 1) CAF with or without an autogenous or non-autogenous soft tissue graft (including CT and acellular dermal matrix [ADM]); 2) GTR using bioabsorbable membranes with or without a bone replacement graft; 3 ) any combination of the above with enamel matrix derivative (EMD).

\section{Exclusion Criteria}

Animal studies and human studies without quantifiable data regarding clinical measurements were not included.

\section{Data Collection and Ranking}

Reviewed studies received a rank score, proposed by the investigators, based on the quality of the study methodology: score 5 = RCT; score 4 = quasi-experimental study (e.g., no randomization); score $3=$ controlled observational study (e.g., cohort or casecontrol investigation); score 2 = observational studies without controls; score 1 = case report or case series.

\section{Statistical Analysis}

Analysis was performed using a statistical package. ${ }^{\dagger}$ Weighted means of gingival thickness, mean root coverage, and complete root coverage (WGT, WMRC, MCRC, respectively) were calculated using particular descriptions and formulas (weight $=\mathrm{W}_{\mathrm{i}}=\mathrm{n}_{\mathrm{i}} /\left[\mathrm{n}_{1}+\mathrm{n}_{2}+\right.$ $\left.n_{3} \ldots+n_{t}\right]$, where $i=1 \ldots . . t ; t=$ the number of studies under consideration; and $\mathrm{n}=$ the number of defects).

Weighting computed in this manner accounted for sample size. The Mann-Whitney test, one-way analy- sis of variance (ANOVA), and simple linear regression analysis were used to identify potential outcomeinfluencing factors on mean and complete root coverage. Differences were deemed statistically significant when $P<0.05$. For the purposes of this examination, the adjunctive use of CT or ADM with CAF was considered simply CT or ADM graft therapy. ADM treatment did not receive statistical analysis.

\section{RESULTS}

\section{Patient, Defect, Treatment, and Study Characteristics}

Fifteen papers, all published between 1999 and 2006, met the criteria established for this review. Tables 1 and 2 present raw data from selected studies. Between 11 and 45 subjects with 14 to 45 buccal recession defects participated in the studies. Four reports incorporated current smokers. The greatest number of smoking patients $(N=7)$ joined a Brazilian study; each consumed 20 cigarettes per day for at least 5 years. ${ }^{40}$ Lastly, the Baldi et al. ${ }^{41}$ group treated five smokers but did not disclose habit specifics. For the most part, clinicians corrected Miller's Class I and/or II recessions, with the exception of Muller et al., ${ }^{42}$ who included Miller's Class III defects. Follow-up times ranged from 3 months to 5 years, although most investigations lasted for 6 months $(N=6)$ or 12 months $(N=5)$.

Studies diverged in types of treatment given as well. Nine studies used a monotherapeutic approach to defects; they used either CAF, CT, GTR, or ADMalone. ${ }^{40-48}$ Another five studies employed adjuncts, which included CAF combined with CT, ADM, or EMD or GTR combined with EMD, hydroxyapatite (HA), or demineralized freeze-dried bone allograft (DFDBA). ${ }^{49-53}$ For analysis, the adjunct use of CT material with CAF was considered CT therapy. In contrast, Paolantonio ${ }^{54}$ compared CT grafting to GTR with or without HA.

Most of the studies chosen $(11 / 15)$ did not perform correlation statistics on mean or complete root coverage in regards to initial gingival thickness; instead, they evaluated changes in thickness postprocedure as a stand-alone parameter (Table 1). RCTs comprised the majority of these studies (7/11). One of the 11 investigations had a quasi-experimental organization. ${ }^{46}$ Of the total 15 groups, four conducted multiple regression analysis in which flap thickness acted as a predictor variable, and mean or complete root coverage acted as the dependent variable. $41,42,44,49$ Case studies comprised all but one of these investigations (Table 2). No study directly segregated subjects into treatment groups by tissue thickness.

\section{Gingival Thickness Measurement}

Few reports concurred on the location at which gingival thickness was recorded. The most coronal

$\dagger$ SPSS, Chicago, IL. 
Table I.

\section{Studies Without Statistical Analysis of Flap Thickness}

\begin{tabular}{|c|c|c|c|c|c|c|}
\hline Reference & Study Score & Treatment Type & $\begin{array}{l}\text { N Subjects } \\
\text { (N defects) }\end{array}$ & N Smokers & Follow-Up Time & Miller Class \\
\hline Gurgan et al. ${ }^{43}$ & । & CAF & $13(26)$ & & 5 years & । \\
\hline da Silva et al. ${ }^{50}$ & 5 & $C A F \pm C T$ & II (22) & 0 & 6 months & 1 \\
\hline Woodyard et al. ${ }^{53}$ & 5 & $C A F \pm A D M$ & $24(24)$ & 0 & 6 months & ।, II \\
\hline Muller et al. ${ }^{45}$ & । & CT & $22(32)$ & 3 & I year & ।, ॥ \\
\hline Martins et al. ${ }^{40}$ & । & CT & $15(18)$ & 7 & 4 months & ।, II \\
\hline Paolantonio et al. ${ }^{47}$ & 5 & CT or ADM & $30(30)$ & 0 & I year & ।, II \\
\hline Muller et al. ${ }^{46}$ & 4 & CT or GTR & $13(14)$ & 2 & 6 months & ।, II \\
\hline Paolantonio ${ }^{54}$ & 5 & $\begin{array}{l}\text { CT or GTR (membrane } \\
\text { alone) or GTR with HA }\end{array}$ & $45(45)$ & 0 & I year & ।, II \\
\hline Trabulsi et al. ${ }^{52}$ & 5 & GTR $\pm E M D$ & $26(26)$ & 0 & 6 months & ।, II \\
\hline Duval et al. ${ }^{51}$ & 5 & $\mathrm{GTR} \pm \mathrm{DFDBA}$ & $14(17)$ & & 6 months & ।, II \\
\hline Bittencourt et al. ${ }^{48}$ & 5 & CAF or CT & $17(34)$ & 0 & 6 months & 1 \\
\hline
\end{tabular}

* Denotes statistical significance between groups.

measurements took place "at the gingival margin"; two groups were evaluated at that region. ${ }^{42,51}$ Other groups measured more quantifiably and apically, beginning at $1 \mathrm{~mm}$ from the $\mathrm{GM}(\mathrm{N}=3),{ }^{43,47,54}$ then $2 \mathrm{~mm}$ $(\mathrm{N}=4),{ }^{40,44,48,50}$ and finally $3 \mathrm{~mm}(\mathrm{~N}=2) .{ }^{49,52}$ Three investigations measured at the apical extent of the pocket, although the depths remained unspecified. ${ }^{45,46,53}$ Some of above trials made additional thickness recordings at the mucogingival junction (MGJ) $(\mathrm{N}=2)$, the midpoint between the GM and the MGJ $(N=1)$ and the alveolar mucosa (AM) $(N=$ 1). ${ }^{42,50,53}$ Pini Prato et al. ${ }^{41}$ made their only thickness measurement at the midpoint between the MGJ and the flap base.

\section{Mean Baseline Gingival Thickness}

In no case did the mean baseline gingival thickness fall below $0.7 \mathrm{~mm}$. In fact, seven of 15 studies demonstrated a mean initial thickness of $>1 \mathrm{~mm}$, though none surpassed $1.5 \mathrm{~mm} .40,43,44,48,50-52$ Five studies exhibited $<1$ but $>0.7 \mathrm{~mm}$, whereas the last three investigations described a mean baseline gingival thickness $\leq 0.75 \mathrm{~mm}$. Case reports by Baldi et al. ${ }^{41}$ and by Gurgan et al. ${ }^{43}$ revealed, respectively, the least $(0.7$ $\mathrm{mm}$ ) and greatest $(1.46 \mathrm{~mm})$ baseline tissue thickness.

\section{Mean and Complete Root Coverage}

Tables 1 and 2 present mean root coverage and percentage of defects with complete root coverage achieved by each article surveyed. Table 3 compares ranges of root coverage attained, segregated by treatment type. Overall, CAF plus adjunct (CT, ADM, or EMD) garnered the highest $M R C$ range, followed by CT. GTR alone had the widest range of MRC results. With respect to percentage of defects with CRC, the ranges were wider and values typically lower than those regarding MRC. CAF + ADM resulted in the greatest MRC and percentage of defects with CRC, $99 \%$ and $92 \%$, respectively; only one group used this therapy in their 6 -month investigation. ${ }^{53}$ Both Gurgan et al. $^{43}$ and Muller et al. ${ }^{46}$ detected $44.9 \%$ MRC, the former in a 5-year RCT on CAF alone, the latter in a 6-month non-randomized controlled trial using bioabsorbable membrane alone. In another RCT, Trabulsi 
Table I. (continued)

Studies Without Statistical Analysis of Flap Thickness

\begin{tabular}{lccc}
\hline Thickness Measurement Location & $\begin{array}{c}\text { Baseline } \\
\text { Thickness }(\mathrm{mm})\end{array}$ & MRC (\%) & \% Defects \\
With CRC
\end{tabular}

* Denotes statistical significance between groups.

et al. ${ }^{52}$ reported the lowest percentage of defects with CRC at $8 \%$, achieved via GTR + EMD (note the difference in numbers of studies performed and follow-up time between these treatment modalities). Moreover, two papers did not report a percentage of defects with CRC. ${ }^{40,42}$ One other RCT recorded this parameter but did not distinguish between treatment groups; it reported a total of 10 defects out of 17 with complete coverage. ${ }^{51}$

\section{Statistical Correlation}

When statistical analysis involved all studies complied in this review, weighted baseline gingival thickness acted as a predictor for weighted mean and complete root coverage. Simple linear regression established that weighted gingival thickness had a moderate correlation to WMRC and WCRC $(\mathrm{R}=0.646$ and 0.454 , respectively); indeed, WGT accounted for $41.7 \%$ of variability in weighted mean root coverage results and a lesser proportion (20.7\%) in weighted complete root coverage (Tables 4 and 5). On the other hand, follow-up time proved to be irrelevant to weighted root coverage (Tables 4 and 5). As calculated by ANOVA, the type of treatment rendered (i.e., CAF alone, CT alone, GTR alone, and therapy plus adjunct), but not study score, influenced WMRC and WCRC, the latter more so than the former, which achieved only borderline statistical significance $(P=0.061$; Table 6$)$.

When the studies were segregated by treatment modality, an association between weighted gingival thickness and weighted mean root coverage manifested for CT and GTR (membrane alone or with EMD, HA, or DFDBA) therapy (Table 7). Regression analysis revealed that WGT explained $82.6 \%$ and $51.0 \%$ of the variability in weighted mean root coverage for CT and GTR procedures, respectively, with corresponding high positive correlations of 0.909 and 0.714 . No such relationship held for the investigations that performed CAF. Moreover, WGT lost its correlation with weighted complete root coverage when individual treatments were considered alone (Table 8).

To determine whether a minimum baseline gingival thickness existed that ensured a greater root coverage 
Table 2.

\section{Studies With Statistical Analysis of Flap Thickness}

\begin{tabular}{|c|c|c|c|c|c|c|c|c|c|c|c|}
\hline Ref. & $\begin{array}{l}\text { Study } \\
\text { Score }\end{array}$ & $\begin{array}{c}\text { Treatment } \\
\text { Type }\end{array}$ & $\begin{array}{l}N \text { Subjects } \\
(\mathrm{N} \text { defects })\end{array}$ & $\begin{array}{c}\mathrm{N} \\
\text { Smokers }\end{array}$ & $\begin{array}{l}\text { Follow-Up } \\
\text { Time }\end{array}$ & $\begin{array}{l}\text { Miller } \\
\text { Class }\end{array}$ & $\begin{array}{c}\text { Thickness } \\
\text { Measurement } \\
\text { Location }\end{array}$ & $\begin{array}{l}\text { Baseline } \\
\text { Thickness } \\
(\mathrm{mm})\end{array}$ & MRC (\%) & $\begin{array}{l}\text { \% Defects } \\
\text { With CRC }\end{array}$ & $\begin{array}{l}\text { Thickness } \\
\text { MLR } \\
\text { Statistics }\end{array}$ \\
\hline $\begin{array}{l}\text { Baldi } \\
\text { et al. }{ }^{41}\end{array}$ & । & CAF & $19(19)$ & 5 & 3 months & I, II & $\begin{array}{l}\text { Midpoint } \\
\text { between MGJ } \\
\text { and flap base }\end{array}$ & $0.7 \pm 0.2$ & $82 \pm 17$ & 37 & $\begin{array}{l}\text { Thickness } \\
\text { related to } \\
\text { root coverage } \\
\left(\mathrm{R}^{2}=0.89\right) \\
(>0.8 \mathrm{~mm} \\
100 \% \mathrm{CRC} ; \\
<0.8 \mathrm{~mm} \\
\text { partial coverage) }\end{array}$ \\
\hline $\begin{array}{l}\text { Muller } \\
\text { et al. }{ }^{42}\end{array}$ & 1 & GTR & $14(3 \mid)$ & 0 & | year $\mid$ & I, II, III & $\begin{array}{l}\text { 1) } G M \\
\text { 2) } M G J \\
\text { 3) } A M\end{array}$ & 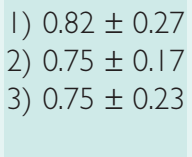 & 51.4 & & $\begin{array}{l}\text { Marginal gingival } \\
\text { thickness related } \\
\text { to attachment } \\
\text { gain }\left(R^{2}=0.46\right)\end{array}$ \\
\hline $\begin{array}{l}\text { Berlucchi } \\
\text { et al. }{ }^{49}\end{array}$ & i I & $C A F+E M D$ & $30(30)$ & 0 & I year & I, I| & $\begin{array}{l}3 \mathrm{~mm} \text { apical } \\
\text { to } \mathrm{GM}\end{array}$ & $0.9 \pm 0.2 *$ & $91.4 \pm 15.5$ & 70 & $\begin{array}{l}\text { Thickness } \\
\text { related to root } \\
\text { coverage } \\
\left(R^{2}=0.55\right)\end{array}$ \\
\hline $\begin{array}{l}\text { Huang } \\
\text { et al. }{ }^{44}\end{array}$ & 5 & CAF & $23(23)$ & 0 & 6 months & I & $\begin{array}{l}2 \mathrm{~mm} \text { apical } \\
\text { to } \mathrm{GM}\end{array}$ & $1.1 \pm 0.3$ & $82.3 \pm 24.7$ & 61 & $\begin{array}{l}\text { Gingival } \\
\text { thickness } \\
\text { associated with } \\
\text { CRC, recession } \\
\text { depth reduction }\end{array}$ \\
\hline
\end{tabular}

* Derived from figure in text of article.

outcome, a Mann-Whitney test was employed to analyze all studies. Setting the threshold baseline thickness limit $>0.75,0.8,0.85,0.9$, and $1.0 \mathrm{~mm}$ failed to generate relevant associations with weighted mean or complete root coverage (two-tailed $P>0.05$ ).

\section{DISCUSSION}

Wound healing after mucogingival surgery relies on clotting, revascularization, and maintenance of the blood supply. ${ }^{55-58}$ Thick gingiva in the recipient site seems to be advantageous as, in theory, it harbors more patent vessels and eases surgical manipulation. Indeed, two trials exist that link thicker tissue to complete root coverage in CAF procedures. ${ }^{41,44}$ Another case report on CAF plus EMD found that gingival thickness correlates to mean root coverage. ${ }^{49}$ According to our analysis, the addition of several more rigorous investigations (i.e., randomized controlled trials) corroborated this previous evidence; as a predictor, study score did not reach statistical significance. It is important to stress that this study examined weighted means of thickness and root coverage, not simply raw patient data, and as such, its findings do not necessarily indicate an analogous relationship with respect to individual data.
From the articles reviewed here, it is apparent that gingival thickness has a bearing on the mean and complete root coverage gained from disparate treatment modalities, in particular CT grafting and GTR. Our results, unlike those from previous studies, did not implicate thickness as an influencing factor for CAF procedures. This occurred due to inclusion of a study that achieved the least amount of root coverage (44.9\%), yet had the highest baseline gingival thickness $(1.46 \mathrm{~mm}) .{ }^{43}$ The removal of this study created a high correlation $(R=0.880)$ between WGT and WMRC for CAF treatment via simple linear regression $(P=0.021)$. To be sure, the "outlier" investigation had the longest follow-up time at 5 years, five to 10 times longer than any of the other reports. Very few trials that involve recession correction last for 1 year, let alone 5 years. ${ }^{59}$ More than half of the studies incorporated in this review lasted $<1$ year. In general, followup time did not associate with root coverage, probably as a few groups achieved somewhat lower-thantypical root coverage results compared to findings reported by meta-analyses, despite a shorter followup time. ${ }^{40,42,45,46,50,53,60-62}$ Certainly, familiarity with a certain treatment technique impacts success. One group that had three investigations included in our 
Table 3.

\section{Comparison of Root Coverage Ranges Between Therapies}

\begin{tabular}{l|c|c|c}
\hline & $\begin{array}{c}\text { N Studies } \\
\text { Performing This } \\
\text { Treatment }\end{array}$ & $\begin{array}{c}\text { Mean Root } \\
\text { Coverage } \\
\text { Range }\end{array}$ & $\begin{array}{c}\text { \% Defects } \\
\text { With CRC } \\
\text { Range }\end{array}$ \\
\hline Treatment & 6 & $45-91$ & $9-61$ \\
\hline CAF alone & 3 & $75-99$ & $18-92$ \\
$\begin{array}{c}\text { CAF + adjunct } \\
\text { (CT, ADM, } \\
\text { or EMD) }\end{array}$ & & & \\
CT alone & 6 & $74-96$ & $39-76$ \\
$\begin{array}{l}\text { ADM alone } \\
\text { GTR alone }\end{array}$ & 1 & 83 & 27 \\
$\begin{array}{l}\text { GTR + adjunct } \\
\text { (EMD, HA, } \\
\text { or DFDBA) }\end{array}$ & 3 & $45-90$ & $11-40$ \\
\hline
\end{tabular}

Table 4.

\section{Regression Analysis for Weighted Mean Root Coverage: All Studies}

\begin{tabular}{|c|c|c|c|c|c|c|}
\hline Variable & Coefficient & SE & $t$ & $\mathrm{R}$ & $R^{2}$ & $P$ Value \\
\hline $\begin{array}{l}\text { Weighted } \\
\text { baseline } \\
\text { gingival } \\
\text { thickness }\end{array}$ & 49.1555 & 12.687 & 3.874 & 0.646 & 0.417 & $0.001 *$ \\
\hline Follow-up time & 0.017 & 0.028 & 0.608 & 0.132 & 0.017 & 0.549 \\
\hline
\end{tabular}

Dependent variable: weighted mean root coverage.

* Statistically significant difference $(P<0.05)$.

Table 5.

Regression Analysis for Weighted Complete Root Coverage: All Studies

\begin{tabular}{lcccccc}
\hline Variable & Coefficient & $S E$ & $t$ & $R$ & $R^{2}$ & $P$ Value \\
\hline $\begin{array}{l}\text { Weighted } \\
\text { baseline } \\
\text { gingival } \\
\text { thickness }\end{array}$ & 30.478 & 14.081 & 2.165 & 0.454 & 0.207 & $0.044 *$ \\
Follow-up time & -0.005 & 0.025 & -0.199 & 0.047 & 0.002 & 0.844 \\
\hline
\end{tabular}

Dependent variable: weighted complete root coverage.

* Statistically significant difference $(P<0.05)$.

review gained $<75 \%$ MRC with CT or GTR. ${ }^{42,45,46}$ Indeed, there may be biased data in this analysis due to the inclusion of multiple studies from two groups. ${ }^{42,45-47,54}$
Table 6.

\section{ANOVA For Weighted Root Coverage: All Studies}

\begin{tabular}{lcccc}
\hline & $\begin{array}{l}\text { Weighted Mean } \\
\text { Root Coverage }\end{array}$ & \multicolumn{2}{c}{$\begin{array}{c}\text { Weighted Complete } \\
\text { Root Coverage }\end{array}$} \\
\hline Variable & $F$ & $P$ Value & $F$ & $P$ Value \\
Study score & 1.313 & 0.291 & 1.703 & 0.212 \\
Treatment type & 2.734 & $0.061^{*}$ & 4.317 & $0.016^{\dagger}$ \\
\hline
\end{tabular}

Dependent variable: weighted mean or complete root coverage.

* Borderline statistical significance.

$\dagger$ Statistically significant difference $(P<0.05)$

Still, time may affect surgical results. Harris ${ }^{63}$ used ADM to cover Miller's Class I and II recession defects and found that mean root coverage dropped from $93.4 \%$ at roughly 4 months to $65.8 \%$ at about 4 years. However, with the use of CT grafts, the mean root coverage did not change (97\% at 4 weeks and 4 months). Another group ${ }^{1}$ found coronal repositioning of the GM at least 1 month after surgical intervention, not further recession. Reports ${ }^{1,2,4,8,64-74}$ on free gingival and CT grafting, crown lengthening, and ADM document this phenomenon, termed "creeping attachment." The amount gained coronally ranges from 0.43 to $3 \mathrm{~mm}$, with a rough average of $1 \mathrm{~mm}$ gained, and a trial from Matter ${ }^{4}$ suggests that the position 1 year after surgery remains stable at 5 years post-surgery, at least for free gingival grafts. Few factors accurately predict the formation of creeping attachment, but some investigators advocate that narrow initial defects, isolated defects, tooth position, oral hygiene factors, younger patients, and thick gingiva encourage it. ${ }^{70}$ In a crownlengthening study, a "thick" tissue biotype, assessed by observation only, correlated to about $3 \mathrm{~mm}$ of coronal displacement $(P=0.001) \cdot{ }^{73}$ The proper evaluation of the effect of gingival thickness on root coverage stability (i.e., no change, further recession, or creeping attachment) necessitates more investigations with greater follow-up times.

Within the limits of our analysis, it is not possible to conclude anything definitive regarding minimum tissue thickness, or critical thickness threshold, required for a predicable root coverage outcome, due in part to significant measurement and treatment disparities between studies. Only 15 studies met our inclusion criteria, and only $29 \%$ of those $(\mathrm{N}=4)$ examined gingival thickness as a predictor for root coverage. Investigations varied greatly in the location of thickness evaluation and therapeutic method. The vast majority of studies measured thickness, coronal to the MGJ but at different levels, in both free and attached gingiva. It is unknown whether thickness at a particular 
Table 7.

\section{Regression Analysis For Weighted Mean Root Coverage: Segregation By Treatment}

\begin{tabular}{lcccccc}
\hline Treatment & Coefficient & SE & $t$ & $R$ & $R^{2}$ & $P$ Value \\
\hline CAF alone & 12.770 & 20.655 & 0.618 & 0.295 & 0.087 & 0.570 \\
$\begin{array}{c}\text { CAF monotherapy } \\
\text { or with adjunct }\end{array}$ & 27.183 & 28.270 & 0.962 & 0.395 & 0.156 & 0.380 \\
CT alone & 98.706 & 18.514 & 5.331 & 0.909 & 0.826 & $0.002^{*}$ \\
$\begin{array}{c}\text { GTR alone } \\
\begin{array}{c}\text { GTR monotherapy } \\
\text { or with adjunct }\end{array}\end{array}$ & 48.251 & 19.057 & 2.532 & 0.825 & 0.681 & 0.085 \\
\hline
\end{tabular}

Dependent variable: weighted mean root coverage.

* Statistically significant difference $(P<0.05)$.

Table 8.

\section{Regression Analysis For Weighted Complete Root Coverage: Segregation By Treatment}

\begin{tabular}{lccccccc}
\hline Treatment & Coefficient & SE & $t$ & $R$ & $R^{2}$ & $P$ Value \\
\hline CAF alone & 8.059 & 21.571 & 0.374 & 0.184 & 0.034 & 0.728 \\
$\begin{array}{c}\text { CAF monotherapy } \\
\text { or with adjunct } \\
\text { CT alone }\end{array}$ & 22.810 & 29.168 & 0.782 & 0.330 & 0.109 & 0.470 \\
$\begin{array}{c}\text { GTR alone } \\
\begin{array}{c}\text { GTR monotherapy } \\
\text { or with adjunct }\end{array}\end{array}$ & -13.953 & 60.224 & 29.289 & 1.373 & 0.566 & 0.320 & 0.242 \\
\hline
\end{tabular}

Dependent variable: weighted complete root coverage.

position is an influencing factor. In fact, three studies measured thickness at two or three sites on the same defect. ${ }^{42,50,53}$ One of these studies scrutinized marginal gingival thickness statistically and linked it to attachment gain, not root coverage. ${ }^{42}$ Regardless of measurement location, all investigations reported a minimum of $0.7 \mathrm{~mm}$ mean gingival thickness. Thirteen of 15 studies exhibited a mean thickness $\geq 0.8$ $\mathrm{mm}$ in at least one treatment group; this meets the thickness criterion for root coverage success proposed by Baldi et al. ${ }^{38}$ and Allen and Miller ${ }^{41}$ for CAF. It is possible that further increases in dimension fail to enhance root coverage after a particular threshold thickness is met, which is reflected by the lack of statistical significance observed by this review.

As mentioned above, comparing results from one therapy to another, especially concerning gingival thickness, proves difficult. Healing proceeds differently in CAF, CT grafting, and GTR; the two latter methods involve the insertion of material between the root/recipient bed and the overlying flap. In CT grafting, the material contains vessels and cells, which the barrier employed in GTR does not possess. Most importantly, CAFs and GTR have, supposedly, a constant, relatively intact blood supply, whereas the donor tissue in a two-site graft procedure initially requires plasmatic circulation, followed by vessel growth and anastamoses. $8,56,75$ Thus, revascularization occurs in a distinctly dissimilar manner, and the effect of flap thickness probably varies. With respect to CT grafting, most studies endeavored to position the flap coronally to cover the graft; two groups diverged from this. Muller et al., ${ }^{45,46}$ in different reports, employed a modified envelope technique. $\mathrm{Al}$ ternately, Paolantonio ${ }^{54}$ covered the CT graft with a double pedicle flap. The number of vertical releasing incisions that were made negatively affected blood supply; perhaps with more of them, flap thickness would develop as a greater consequence.

Flap thickness became a more customary clinical measurement only recently. Relatively few reports gauge it or consider its influence on mucogingival treatment outcomes. Data from this review imply that thicker tissue improves clinical results but are unable to establish conclusively a minimum thickness requirement due to a dearth of standardized investigations. To our knowledge, there is no publication that segregates root coverage by type or healing pattern with respect to tissue thickness. To confirm if gingival thickness is essential to mean or complete root coverage or other parameters of success (i.e., attachment gain), many more randomized controlled trials with concordant baseline and outcome measurements are needed. Flap thickness remains a promising potential forecaster of root coverage; nevertheless, its true effect requires further elucidation.

\section{CONCLUSIONS}

1. A critical threshold thickness for root coverage success may exist, as suggested by a limited number of investigations, but studies vary significantly in treatment, measurement, and statistical methodology, rendering concrete evidence difficult.

2. No controlled trials exist that specifically explore the effect of baseline flap thickness on root coverage outcome measurements. These are needed to provide solid evidence for and clarification of the above conclusions. 


\section{ACKNOWLEDGMENT}

This study was partially supported by the Periodontal Graduate Student Research Fund, University of Michigan.

\section{REFERENCES}

1. Borghetti A, Gardella JP. Thick gingival autograft for the coverage of gingival recession: A clinical evaluation. Int J Periodontics Restorative Dent 1990;10:216-229.

2. Harris RJ. Creeping attachment associated with the connective tissue with partial-thickness double pedicle graft. J Periodontol 1997;68:890-899.

3. Kois JC. Predictable single-tooth peri-implant esthetics: Five diagnostic keys. Compend Contin Educ Dent 2004;25:895-896, 898, 900 passim; quiz 906-897.

4. Matter J. Creeping attachment of free gingival grafts. A five-year follow-up study. J Periodontol 1980;51: 681-685.

5. Muller HP, Eger T. Masticatory mucosa and periodontal phenotype: A review. Int $J$ Periodontics Restorative Dent 2002;22:172-183.

6. Muller HP, Heinecke A, Schaller N, Eger T. Masticatory mucosa in subjects with different periodontal phenotypes. J Clin Periodontol 2000;27:621-626.

7. Muller HP, Schaller N, Eger T, Heinecke A. Thickness of masticatory mucosa. J Clin Periodontol 2000;27: 431-436.

8. Nelson SW. The subpedicle connective tissue graft. A bilaminar reconstructive procedure for the coverage of denuded root surfaces. J Periodontol 1987;58:95-102.

9. Serino G, Wennström JL, Lindhe J, Eneroth L. The prevalence and distribution of gingival recession in subjects with a high standard of oral hygiene. J Clin Periodontol 1994;21:57-63.

10. Wennström J, Lindhe J. Plaque-induced gingival inflammation in the absence of attached gingiva in dogs. $J$ Clin Periodontol 1983;10:266-276.

11. Wennström J, Lindhe J. Role of attached gingiva for maintenance of periodontal health. Healing following excisional and grafting procedures in dogs. J Clin Periodontol 1983;10:206-221.

12. Folke LE, Stallard RE. Periodontal microcirculation as revealed by plastic microspheres. J Periodontal Res 1967;2:53-63.

13. Keller GJ, Cohen DW. India ink perfusions of the vascular plexus of oral tissues. Oral Surg Oral Med Oral Pathol 1955;8:539-542.

14. Mormann W, Ciancio SG. Blood supply of human gingiva following periodontal surgery. A fluorescein angiographic study. J Periodontol 1977;48:681-692.

15. Egelberg J. The blood vessels of the dento-gingival junction. J Periodontal Res 1966;1:163-179.

16. Kindlova $M$. The blood supply of the marginal periodontium in Macacus rhesus. Arch Oral Biol 1965;10: 869-874.

17. Kindlova M. Vascular supply of the periodontium in periodontitis. Int Dent $J$ 1967;17:476-489.

18. Kindlova M. Development of vessels in the marginal periodontium in rats. J Dent Res 1968;47:507.

19. Kindlova M. The development of the vascular bed of the marginal periodontium. J Periodontal Res 1970;5: 135-140.

20. Kindlova M, Matena V. Blood vessels of the rat molar. $J$ Dent Res 1962;41:650-660.

21. Lenz P. The structure of the vessels of the marginal periodontium, scanning electron microscopic studies (in German). Dtsch Zahnarztl Z 1974;29: 868-870.

22. Mormann W, Meier C, Firestone A. Gingival blood circulation after experimental wounds in man. $J$ Clin Periodontol 1979;6:417-424.

23. Caffesse RG, Castelli WA, Nasjleti CE. Vascular response to modified Widman flap surgery in monkeys. $J$ Periodontol 1981;52:1-7.

24. Kon S, Novaes AB, Ruben MP, Goldman HM. Visualization of the microvascularization of the healing periodontal wound. IV. Mucogingival surgery: Full thickness flap. J Periodontol 1969;40:441-456.

25. Bhaskar SN, Cutright DE, Beasley JD, Perez B, Hunsuck EE. Healing under full and partial thickness mucogingival flap in the miniature swine. J Periodontol 1970;41:675-682.

26. Itoiz ME, Litwack D, Kennedy JE, Zander HA. Experimental ischemia in monkeys. 3. Histochemical analysis of gingival epithelium. J Dent Res 1969;48:895-900.

27. Kennedy J. Experimental ischemia in monkeys. II. Vascular response. J Dent Res 1969;48:888-894.

28. Kennedy JE. Effect of inflammation on collateral circulation of the gingiva. J Periodontal Res 1974;9:147-152.

29. Kennedy JE, Zander HA. Experimental ischemia in monkeys. I. Effect of ischemia on gingival epithelium. $J$ Dent Res 1969;48:696-701.

30. Tissot RJ, Sullivan HC. Evaluation of the survival of partial thickness and full thickness flaps. $J$ Dent Res 1971;170(Abstr. 470).

31. Wood DL, Hoag PM, Donnenfeld OW, Rosenfeld LD. Alveolar crest reduction following full and partial thickness flaps. J Periodontol 1972;43:141-144.

32. Staffileno H, Levy S, Gargiulo A. Histologic study of cellular mobilization and repair following a periosteal retention operation via split thickness mucogingival flap surgery. J Periodontol 1966;37:117-131.

33. Wilderman MN, Pennel BM, King K, Barron JM. Histogenesis of repair following osseous surgery. J Periodontol 1970;41:551-565.

34. Claffey N, Shanley D. Relationship of gingival thickness and bleeding to loss of probing attachment in shallow sites following nonsurgical periodontal therapy. J Clin Periodontol 1986;13:654-657.

35. Anderegg CR, Metzler DG, Nicoll BK. Gingiva thickness in guided tissue regeneration and associated recession at facial furcation defects. $J$ Periodontol 1995;66:397-402.

36. McFall WT Jr. The laterally repositioned flap - criteria for success. Periodontics 1967;5:89-92.

37. Clodius L, Smahel J. Thin and thick pedicle flap. Acta Chir Plast 1972;14:30-35.

38. Allen EP, Miller PD Jr. Coronal positioning of existing gingiva: Short-term results in the treatment of shallow marginal tissue recession. J Periodontol 1989;60:316-319.

39. Harris RJ. A comparative study of root coverage obtained with guided tissue regeneration utilizing a bioabsorbable membrane versus the connective tissue with partial-thickness double pedicle graft. J Periodontol 1997;68:779-790.

40. Martins AG, Andia DC, Sallum AW, Sallum EA, Casati MZ, Nociti FH Jr. Smoking may affect root coverage outcome: A prospective clinical study in humans. J Periodontol 2004;75:586-591.

41. Baldi C, Pini-Prato G, Pagliaro U, et al. Coronally advanced flap procedure for root coverage. Is flap thickness a relevant predictor to achieve root coverage? A 19-case series. J Periodontol 1999;70:1077-1084. 
42. Muller HP, Stahl M, Eger T. Dynamics of mucosal dimensions after root coverage with a bioresorbable membrane. J Clin Periodontol 2000;27:1-8.

43. Gurgan CA, Oruc AM, Akkaya M. Alterations in location of the mucogingival junction 5 years after coronally repositioned flap surgery. J Periodontol 2004;75: 893-901.

44. Huang LH, Neiva RE, Wang HL. Factors affecting the outcomes of coronally advanced flap root coverage procedure. J Periodontol 2005;76:1729-1734.

45. Muller HP, Eger T, Schorb A. Gingival dimensions after root coverage with free connective tissue grafts. J Clin Periodontol 1998;25:424-430.

46. Muller HP, Stahl M, Eger T. Root coverage employing an envelope technique or guided tissue regeneration with a bioabsorbable membrane. J Periodontol 1999; 70:743-751.

47. Paolantonio M, Dolci M, Esposito P, et al. Subpedicle acellular dermal matrix graft and autogenous connective tissue graft in the treatment of gingival recessions: A comparative 1-year clinical study. J Periodontol 2002;73:1299-1307.

48. Bittencourt S, Del Peloso Ribeiro E, Sallum EA, Sallum AW, Nociti FH, Casati MZ. Comparative 6-month clinical study of a semilunar coronally positioned flap and subepithelial connective tissue graft for the treatment of gingival recession. J Periodontol 2006;77:174-181.

49. Berlucchi I, Francetti L, Del Fabbro M, Basso M, Weinstein RL. The influence of anatomical features on the outcome of gingival recessions treated with coronally advanced flap and enamel matrix derivative: A 1-year prospective study. J Periodontol 2005;76:899-907.

50. da Silva RC, Joly JC, de Lima AF, Tatakis DN. Root coverage using the coronally positioned flap with or without a subepithelial connective tissue graft. $J$ Periodontol 2004;75:413-419.

51. Duval BT, Maynard JG, Gunsolley JC, Waldrop TC. Treatment of human mucogingival defects utilizing a bioabsorbable membrane with and without a demineralized freeze-dried bone allograft. $J$ Periodontol 2000;71:1687-1692.

52. Trabulsi M, Oh TJ, Eber R, Weber D, Wang HL. Effect of enamel matrix derivative on collagen guided tissue regeneration-based root coverage procedure. J Periodontol 2004;75:1446-1457.

53. Woodyard JG, Greenwell H, Hill M, Drisko C, Iasella JM, Scheetz J. The clinical effect of acellular dermal matrix on gingival thickness and root coverage compared to coronally positioned flap alone. J Periodontol 2004;75:44-56.

54. Paolantonio $M$. Treatment of gingival recessions by combined periodontal regenerative technique, guided tissue regeneration, and subpedicle connective tissue graft. A comparative clinical study. J Periodontol 2002; 73:53-62.

55. Guiha R, el Khodeiry S, Mota L, Caffesse R. Histological evaluation of healing and revascularization of the subepithelial connective tissue graft. J Periodontol 2001; 72:470-478.

56. Oliver RC, Löe H, Karring T. Microscopic evaluation of the healing and revascularization of free gingival grafts. J Periodontal Res 1968;3:84-95.

57. Sullivan HC, Atkins JH. Free autogenous gingival grafts. I. Principles of successful grafting. Periodontics 1968;6:121-129.
58. Wilderman MN, Wentz FM. Repair of a dentogingival defect with a pedicle flap. J Periodontol 1965;36:218-231.

59. Oates TW, Robinson M, Gunsolley JC. Surgical therapies for the treatment of gingival recession. A systematic review. Ann Periodontol 2003;8:303-320.

60. Clauser C, Nieri M, Franceschi D, Pagliaro U, Pini-Prato G. Evidence-based mucogingival therapy. Part 2: Ordinary and individual patient data meta-analyses of surgical treatment of recession using complete root coverage as the outcome variable. J Periodontol 2003; 74:741-756.

61. Pagliaro U, Nieri M, Franceschi D, Clauser C, Pini-Prato G. Evidence-based mucogingival therapy. Part 1: A critical review of the literature on root coverage procedures. J Periodontol 2003;74:709-740.

62. Roccuzzo M, Bunino M, Needleman I, Sanz M. Periodontal plastic surgery for treatment of localized gingival recessions: A systematic review. J Clin Periodontol 2002;29():178-194.

63. Harris RJ. A short-term and long-term comparison of root coverage with an acellular dermal matrix and a subepithelial graft. J Periodontol 2004;75:734-743.

64. Bell LA, Valluzzo TA, Garnick JJ, Pennel BM. The presence of "creeping attachment" in human gingiva. J Periodontol 1978;49:513-517.

65. Borghetti A, Louise F. Controlled clinical evaluation of the subpedicle connective tissue graft for the coverage of gingival recession. J Periodontol 1994;65:1107-1112.

66. Bragger U, Lauchenauer D, Lang NP. Surgical lengthening of the clinical crown. J Clin Periodontol 1992;19: 58-63.

67. Dorfman HS, Kennedy JE, Bird WC. Longitudinal evaluation of free autogenous gingival grafts. A fouryear report. J Periodontol 1982;53:349-352.

68. Fagan F. Clinical comparison of the free soft tissue autograft and partial thickness apically positioned flappreoperative gingival or mucosal margins. J Periodontol 1975;46:586-595.

69. Haeri A, Parsell D. Creeping attachment: Autogenous graft vs dermal matrix allograft. Compend Contin Educ Dent 2000;21:725-729; quiz 730.

70. Matter J, Cimasoni G. Creeping attachment after free gingival grafts. J Periodontol 1976;47:574-579.

71. Otero-Cagide FJ, Otero-Cagide MF. Unique creeping attachment after autogenous gingival grafting: Case report. J Can Dent Assoc 2003;69:432-435.

72. Pollack RP. Bilateral creeping attachment using free mucosal grafts. A case report with 4-year follow-up. J Periodontol 1984;55:670-672.

73. Pontoriero R, Carnevale G. Surgical crown lengthening: A 12-month clinical wound healing study. $J$ Periodontol 2001;72:841-848.

74. Ward VJ. A clinical assessment of the use of the free gingival graft for correcting localized recession associated with frenal pull. J Periodontol 1974;45:78-83.

75. Mormann W, Bernimoulin JP, Schmid MO. Fluorescein angiography of free gingival autografts. J Clin Periodontol 1975;2:177-189.

Correspondence: Dr. Debby Hwang, Graduate Periodontics, University of Michigan School of Dentistry, $1011 \mathrm{~N}$. University, Ann Arbor, MI 48109. Fax: 203/254-9201; e-mail: debbyh@umich.edu.

Accepted for publication May 4, 2006. 